\section{The Results of Elections for the Śląskie Voivodeship Assembly in 2018 in the Reality of Territorial Heteronomy}

\author{
Malgorzata Myśliwiec
}

University of Silesia, Poland

https://orcid.org/0000-0002-7149-6977
Political Preferences

2019, vol. 23: 23-36 journals.us.edu.pl/index.php/PP Submitted: 23/06/2019 Accepted: 10/07/2019

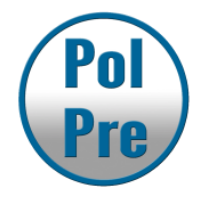

\begin{abstract}
:
The main aim of the paper is the theoretical analysis of the concept of the territorial heteronomy. Conclusions concerning the idea of territorial autonomy, regionalism or federalism easily can be found in the scientific literature. But they are useless to investigate and explain many political processes and political preferences in states of the Central and Eastern Europe. It is because states of this part of the continent did not have a chance to create and develop their own models of classic administration institutions in the nineteenth century, inter alia the local and regional government. Their only experience in this area is limited to the interwar period between 1918 and 1939. They have gained a new chance for a democratic division of public tasks after the collapse of the communist system in the very end of the twentieth century. But in that period they have focused more on the horizontal division of powers than on the vertical one. For that reason up till today political phenomena in the political centre have more importance than the regional policy impact attempts. The inspiration for such a research were electoral results obtained by two regional parties at elections to the Śląskie Voivodeship Assembly in 2018.
\end{abstract}

Keywords: territorial heteronomy, territorial autonomy, Silesia, regional parties, Śląskie Voivodeship, elections

\title{
Introduction
}

On October 21, 2018 local and regional government elections took place in Poland. Among the other representative bodies, the composition of the Śląskie Voivodeship Assembly was also elected. These elections paid a particular attention to the researchers involved in problems related to the operation of regional parties in Europe. It was because for the first time since 2010 none of the Silesian regional parties won seats in the regional body adopting enactments of regional law. 
The main aim of this paper is to analyze the concept of the territorial heteronomy in the reality of political competition during the elections to the voivodeship assemblies in Poland. Its specifics seem to favour electoral preferences related to the votes cast on statewide parties, and not regional parties.

The inspiration for such research were electoral results achieved by two regional parties at elections to the Śląskie Voivodeship Assembly in 2018. The case of Silesia is particularly interesting, because this is the only Polish region that in the period between the two World Wars in the 20. century had the territorial autonomy (Ciagwa 1988). Despite the fact that it was a legal solution applied only on a part of the historical territory of Silesia, granted to Poland after the 1921 plebiscite, the memory of owned political rights is very strong in the region until today. Although relations between political center and peripheries in contemporary Poland can be defined as a classic example of territorial heteronomy, political behaviors in Silesia differ from those that are typical of all other regions of the state.

The research question stated before the research was as follows: what are the characteristics of the phenomenon of the territorial heteronomy?

The adopted research hypothesis was: the ideal-type of the territorial heteronomy is the exact opposite phenomenon to the ideal-type of an institutionally fully-developed and autonomous regional political system. A political system of this type creates more attractive conditions for political rivalry of statewide parties and can be a favourable factor to cast electoral votes on them and not on regional parties.

The survey methodology is based on the institutional and legal analysis method. The starting point for the research is the concept of the ideal-type of an institutionally fully developed and autonomous regional political system, presented in 2018 by Régis Dandoy, Giulia Sandri and Lieven De Winter (2018: 135-136).

\section{Two Silesian regional parties in the 2018 local government elections}

On August 13, 2018, the local government elections were ordered by the Prime Minister Mateusz Morawiecki. Elections to municipal councils, poviat councils, voivodeship assemblies and district councils of the capital city of Warsaw were announced to be held on October 21, 2018, as well as the first round of elections of mayors and city presidents. The particular attention of researchers investigating problems related to the operation of regional parties in Europe has focused on the political rivalry in Śląskie Voivodeship. It was because for the first time in Poland 
after 1989 two regional political parties: the Silesian Regional Party (Śląska Partia Regionalna ŚPR) and the Silesians Together (Ślonzoki Razem - SR) took part in this type of elections. Moreover, for the first time the Silesian Autonomy Movement (Ruch Autonomii Ślaska - RAŚ) did not participate in the regional elections. It is an association, which has consistently had its representation in the Śląskie Voivodeship Assembly and has also almost continuously co-created the regional executive since 2010. In 2019 the leadership of RAŚ decided to take part in elections not under its own name, but as part of a wider political project that was to be the Silesian Regional Party. On June 21, 2017 Henryk Mercik and Grzegorz Franki, leaders of two biggest and most influential regional associations - the Silesian Autonomy Movement (created in 1990) and the Upper-Silesian Union (Zwiazek Górnoślaski - ZG, created in 1989) -announced the creation of the first regional party in Poland after 1989 (Pawlik 2017a). At the beginning, the project looked very promising. Particularly, hoping for its success was the favourable attitude of the President of ZG, Grzegorz Franki (Pawlik 2017b). In the past, the problem for the unification of the regional forces of these two major associations was the reluctant attitude of the ZG leaders to such a project. The hope, however, did not last long. In the end of November 2017 Grzegorz Franki has announced his resignation from the project. Despite the fact that it did not mean the end of the Silesian Regional Party, it has significantly weakened it before the local and regional election. Grzegorz Franki, despite the chance of becoming the leader of the first regional party in Poland after 1989, has chosen a career in the statewide party Civic Platform (Zasada 2017).

Finally, in the elections to the Sląskie Voivodeship Assembly, the Silesian Regional Party has gained 3.10\% of votes cast in the voivodship, and the Ślonzoki Razem gained 3,23\%. This meant that none of the regional parties exceeded $5 \%$ of the electoral threshold and could not take part in the distribution of seats.

The situation described above shows that in modern Poland not only the results of regional elections, but also the attitudes of leaders of political parties and associations indicate that the attractiveness of statewide parties is greater for them than that of the regional ones. This may be particularly puzzling in the case of Upper Silesia, because it is the only region of Poland that between the two World Wars in the twentieth century had territorial autonomy. The intellectual tradition of this systemic solution has returned after the 1989 transition. At that time, social and political associations began to emerge, gathering activists of the Silesian movement. But the 2019 local and regional elections have shown that the construction of the Polish political system greatly diminishes the chances of regional parties for the emergence and relevance of political success. 


\section{An institutionally fully developed and autonomous regional political system}

To understand the influence of the construction of the political system in Poland, related to the vertical division of public tasks, on political preferences of voters and political leaders, the concept of territorial heteronomy should be analyzed first. The useful theoretical construction to refer in this case is the ideal-type of an institutionally fully developed and autonomous regional political system, presented in 2018 by Régis Dandoy, Giulia Sandri and Lieven De Winter (2018: 135-136). The authors have pointed for eleven features that should characterise it. They were:

1. The region existence is guaranteed by constitutional or other basic law;

2. The region has its own constitution that specifies its competencies in which the state level cannot interfere;

3. Revision of the state constitution (regarding the division of competences between state and region) can only be made by co-decision between state and regions (under consensus or special majority rule);

4. Proper policy competencies are guaranteed by constitutional or other basic law;

5. The region has a directly elected regional assembly and is granted classical parliamentary functions (legislation, executive oversight, government making);

6. The region is autonomous in the design of regional or sub-regional (local) institutions;

7. The region has the right to appeal to a constitutional or other higher (federal) court to solve conflicts with the state level;

8. The region has a constitutional court or other specialized courts to autonomously solve conflicts between actors within the regional political system (like in US states);

9. The region participates in the decision-making at the national level though a guaranteed representation in a second chamber, or through other explicit provisions or intergovernmental agreements for policy coordination;

10. The region participates in EU decision-making when matters of (executive) regional competence are treated by the European Council of Ministers, through a variety of ways;

11. The region enjoys large taxing and spending autonomy.

Nevertheless, after indicating these features, the authors point unambiguously that: "Currently, no European region enjoys fully the entire set of these institutional development and autonomy features." (Dandoy et al. 2018: 136). The problem is, that in the case of Poland none of them can be confirmed. 


\section{“The region existence is guaranteed by constitutional or other basic law."}

In Constitution of the Republic of Poland of 1997 no regulations concerning regions are included. The most probable reason to explain this situation is the fact that at the time of the constitution adoption the state was still divided into forty-nine small voivodeships. They were the heritage of the administrative division made in the 1970s, in reality of non-democratic political system. The process of political transition in Poland has begun at the beginning of 1980s. It has brought a redefinition of relationship in the horizontal division of powers (between the legislative, executive and judiciary branch) and restored a local self-government in the form of communes. The next stage of the reform, concerning the vertical division of power, was implemented in 1998. Its effect was the creation of 373 poviats (intermediate level between the commune and the region), as well as the division of Poland into 16 voivodeships. The reform of the administrative division, later than the adoption of the Constitution, resulted in the fact that regions have not been included in its regulations. It means that they have no constitutional guarantee of existence. They can be liquidated by the ordinary law, adopted by the central parliament.

"The region has its own constitution that specifies its competencies in which the state level cannot interfere."

The situation in Poland can be described as the total opposition to this idea. The existence of all regional self-government entities is based on one law, adopted by the central, state parliament. Moreover, voivodeships do not participate formally in that process. None of their organs is able to present projects of law, improving functioning of self-government at this level. The idea is that the same regulation should serve all 16 voivodeships. It means in practice, that the regulation does not consider significant historical, economic, demographic or even geographic regional differences between the biggest administrative units in Poland.

\section{"Revision of the state constitution (regarding the division of competences between state and} region) can only be made by co-decision between state and regions (under consensus or special majority rule)."

The Polish Constitution of April 2, 1997 change proceeding regulates article 235 of this act. According to it, a bill to amend the Constitution may be submitted by the following: at least one-fifth of the statutory number of Deputies, representing Sejm (the first chamber of Parliament); the Senate (the second chamber of parliament); or the President of the Republic. 
Firstly, the project is proceeded in Sejm, where it requires 2/3 of votes to be adopted. Then is passed to Senat, where the absolute majority of votes is required. Moreover, if a bill to amend the Constitution relates to the provisions of Chapters I, II or XII, the subjects entitled to submit such a bill may require, within 45 days of the adoption of the bill by the Senate, the holding of a confirmatory referendum. Such subjects shall make application in the matter to the Marshal of the Sejm, who shall order the holding of a referendum within 60 days of the day of receipt of the application. The amendment to the Constitution shall be deemed accepted, if the majority of those voting express support for such an amendment. Anyhow, the referendum is not compulsory. In practice it means that about the revision of the state constitution mainly decide statewide parties. Because of the shape of the electoral system they are the only entities which can obtain the majority of the seats at both chambers of Polish parliament. For this reason, they are also only subjects which have a potential possibility to change the Constitution. Administrative regions do not have any legal competences in this process.

\section{“Proper policy competencies are guaranteed by constitutional or other basic law.”}

Like it was mentioned above, no regulations concerning Polish regions can be found in the text of Polish Constitution. For this reason, it does not contain information about its competences. This element is the subject of law regulation, adopted by the central parliament. It means, that regions depend in this sphere Polish totally on the political will of the representatives of statewide parties, without any constitutional guarantee.

\section{"The region has a directly elected regional assembly and is granted classical parliamentary functions (legislation, executive oversight, government making).”}

The idea of the regional representation, elected in free and direct election, has got the form of the Regional Assembly (sejmik wojewódzki). It is elected for the 5 years term. Its composition depends on the number of inhabitants of voivodeship. Each Regional Assembly is composed of thirty councillors in voivodships with up to 2,000,000 inhabitants and three additional councillors for each subsequent 500,000 inhabitants commenced. The division of seats between presented lists of candidates is made in proportion to the total number of validly cast votes. The $\mathrm{d}$ 'Hondt method is used for the division. In the distribution of seats can participate those lists on which at least $5 \%$ of valid votes were cast in voivodeship.

The regional assembly elects the executive body, that is called the Council of Voivodeship (zarząd województwa). It is composed by its head, called the Marshall of 
Voivodeship (marszałek województwa), vice-marshalls and members. The Council is politically responsible before the Regional Assembly.

It seems - at the very first sight - that the construction fits to the idea presented in the theoretical proposal that we refer to in this paper. However, the Regional Assembly is not equipped by the basic competence for the model: it does not have any legislative competence. It can only adopt the regional laws that in the hierarchy of Polish legal acts are inferior to laws adopted by the central parliament and therefore must be in accordance with the central laws.

\section{“The region is autonomous in the design of regional or sub-regional (local) institutions."}

In Polish model of decentralization all levels of administrative division depend on the central parliament and government. The structure of three levels of Polish self-government is fully controlled by central authorities of the state.

The first level - communes - was created in 1990, just after the first partly democratic elections after the communism collapse. The law about the self-governemt (called this way at the moment) was adopted by the state parliament on March 8, 1990. In this act all aspects of institutional organization and competences of communes were regulated. On the legal basis of this document Poland was divided into 2479 administrative entities of this type. It means that the law equips all Polish communes with the same competences and structure. It also means, that only the state parliament has possibility to revise the law. At the same time communes do not have any competence to present the project of revision of the law that regulates their existence. What is worth to mention is the fact, that although Polish communes were created in a quite artificial way - not like local groups of citizens, living in the area, but like entities with possibility to offer public services - they have the legal possibility to ask the central government to revise their boundaries. If the local community wants to change it, it can ask the Prime Minister to organize the local referendum. If it succeeds, the central government can change administrative boundaries of the commune.

Those same rules concern the second level of the Polish self-government, called poviats. It was created at the same time that the regional self-government of voivodeships in 1998. Almost ten years after the democratic transition the central government of Jerzy Buzek has decided to complete the administrative reform of the state. At June 5, 1998 two laws were adopted by the Polish parliament: about the poviat and voivodeships self-government. 
The law about poviats has regulated their institutional structure and competences. Like in the case of communes, one centrally adopted law regulates the functioning of 380 poviats. They do not have any possibility to participate formally at the process of revision of concerning them legal base. However, also like communes, they can present the demand to the state government to change their boundaries.

The most serious controversies concern the regional level of voivodeships. First of all, the administrative division of the state into 16 entities was the result of the central consensus of statewide parties, without the place for opinion of regional communities of citizens (Dudek 2013: 458-459). The latter were not asked with whom they would want to create the administrative region. On June 5, 1998 the law - one for all voivodeships - was adopted by the state parliament. It has the inferior position that the regulations of Constitution. It equips all administrative regions at the same competences and obligate to create the same institutions. What is also worth to mark, the communes and poviats have a legal possibility to postulate the revision of their boundaries by the state government. Voivodeships have not been equipped with this kind of competence.

The conclusion is that Polish regions have neither the legal possibility to decide about their territorial shape, nor autonomy to design of regional or sub-regional (local) institutions.

\section{"The region has the right to appeal to a constitutional or other higher (federal) court to solve conflicts on the state level."}

According to the article 22, point 9, §2 of the act of 14 June 1960 Code of Administrative Procedure Poland: "Jurisdictional disputes between local government bodies and national government bodies shall be settled by an administrative court". It means that regions, (as well as communes and poviats) are regarded in Polish law as a part of the public administration system and not as constitutionally recognized subjects.

According to the article 188 of Polish Constitution of 1997, the constitutive organs of units of local and regional government may make application to the Constitutional Tribunal regarding the following matters:

1. the conformity of statutes and international agreements to the Constitution;

2. the conformity of a statute to ratified international agreements whose ratification required prior consent granted by statute;

3. the conformity of legal provisions issued by central State organs to the Constitution, ratified international agreements and statutes; 
4. the conformity to the Constitution of the purposes or activities of political parties;

5. complaints concerning constitutional infringements, as specified in Article 79, para. 1.

"The region has a constitutional court or other specialized courts to autonomously solve conflicts between actors within the regional political system (like in the US states)."

Polish system of the judicial branch is highly centralized. This situation is the effect of the construction of the hierarchy of legal acts, regulated by article 87 of Polish Constitution. According to it, Constitution can be found at the top of the hierarchy and laws just below. If the only institution that can adopt laws is the central, state parliament it means, that the Constitutional Court at the level of the state is enough to resolve constitutional conflicts. Regional Assemblies, operating at the level of voivodeships, do not have competence to adopt laws. Adopted by them legal acts are inferior to the state laws and must be in accordance with them. In case of any doubts whether the regional regulation is according with the state law or constitution, the governor (that is the representative of the central government at the regional level) can send it to be investigated before the administrative court of voivodeship.

No regional constitutional court exists in Poland.

"The region participates in the decision-making at the national level though a guaranteed representation in a second chamber, or through other explicit provisions or intergovernmental agreements for policy coordination."

Polish second chamber of parliament is not a chamber of territorial representation. However, the electoral system differs from the one used in the case of the first chamber. To elect Sejm (the first chamber) the proportional system with the d'Hondt method is used. And to elect Senat (the second chamber) the majority system is used. It makes possible to elect independent candidates, as well as those who represent political parties. But analyzing general rules of electoral systems in both cases, it can be observed that their effects are very similar. Both chambers are representing voting citizens, so they have the same character. The idea to transform the second chamber into the real territorial representation is present at political programmes of the Silesian Autonomy Movement (since 2011) and Incubator of the Social Contract (Inkubator Umowy Społecznej - IUS) (since 2019). Anyhow for the moment they are only political proposals presented by two associations that are treated more like the theoretic idea than the main stream political discussion. 
"The region participates in $E U$ decision-making when matters of (executive) regional competence are treated by the European Council of Ministers, through a variety of ways."

The only representation of Poland in the EU decision-making process is always formed by the central, constitutional organs of the state. No formal regional representation to participate is such processes is legally defined.

\section{“The region enjoys large taxing and spending autonomy."}

Poland is a unitary state which means that all key political decisions are adopted at the political centre. It also concerns the taxing system. Polish administrative regions can do not shape their own tax politics.

Local and regional self-government units in Poland participate only in part of the PIT (Personal Income Tax) collected by the state, constituting approximately $17.6 \%$ of the total annual income of the state and part of the CIT (Corporate Income Tax), which revenues account for only about $9.7 \%$ of all state revenues. The act on the income of local and regional selfgovernment units in the article 4 para. 2 and 3 stipulates that the share of communes in income of PIT, from taxpayers living in the area of the commune is $39.34 \%$, while the share in CIT receipts from taxpayers having their seat in the commune is $6,71 \%$. In the case of poviats, the share of these units in the aforementioned taxes, originating from their payers residing or operating in the poviat's territory is $10.25 \%$ of PIT and $1.40 \%$ of CIT (Article 5, para. 2 and 3, respectively). While the voivodship self-government participates in $1.60 \%$ of PIT tax obtained from taxpayers living on its territory and $14.75 \%$ of CIT obtained on the same territory. It should be clearly stated here that local and regional government units in Poland - at any level - do not participate in tax revenues, which bring the highest profits to the central budget. It concerns primarily VAT (Value-Added Tax), from which funds account for over $46.3 \%$ of all annual state revenues per year, and also for excise duty, which provides over $24.1 \%$ of annual revenues of the central budget (NIK 2017).

\section{Conclusions}

The main aim of this paper was to analyze the concept of the territorial heteronomy in reality of the political competition in elections to the voivodeship assemblies in Poland. The inspiration for such research were electoral results achieved by two regional parties (the Silesian Regional Party and the Silesians Together) at the elections to the Śląskie Voivodeship Assembly in 2018. The starting point for the research was the concept of the ideal-type of an institutionally 
fully developed and autonomous regional political system, presented in 2018 by Régis Dandoy, Giulia Sandri and Lieven De Winter. The research question put before the research work began was: what are the characteristics of the phenomenon of the territorial heteronomy? The conducted analysis has shown that the realities of the Polish political system do not meet any of the conditions presented by the authors. Obtained results lead to the conclusion that the case of Poland can be considered as a model example of territorial heteronomy. In opposition to the idea of Régis Dandoy, Giulia Sandri and Lieven De Winter it can be described as the system characterised by the following features:

1. Region existence is not guaranteed by constitutional or other basic law;

2. Region has not its own constitution that specifies its competencies in which the state level cannot interfere;

3. Revision of the state constitution (regarding the division of competences between state and region) is not made by co-decision between state and regions (under consensus or special majority rule);

4. Proper policy competencies are not guaranteed by constitutional or other basic law;

5. Region does not have a directly elected regional assembly and is granted classical parliamentary functions (legislation, executive oversight, government making);

6. Region is not autonomous in the design of regional or sub-regional (local) institutions;

7. Region has not the right to appeal to a constitutional or other higher (federal) court to solve conflicts with the state level;

8. Region has not a constitutional court or other specialized courts to autonomously solve conflicts between actors within the regional political system (like in the US states);

9. Region does not participate in the decision-making at the national level although a guaranteed representation in a second chamber, and other explicit provisions or intergovernmental agreements for policy coordination;

10. Region does not participate in the EU decision-making where matters of (executive) regional competence are treated by the European Council of Ministers, through a variety of ways;

11. Region does not enjoy large taxing and spending autonomy.

The adopted research hypothesis was: the ideal-type of the territorial heteronomy is the exact opposite phenomenon to the ideal-type of an institutionally fully developed and autonomous regional political system. It is a system that in provisions of constitution neither 
guarantees the existence of political authorities at the regional level nor defines their competences. For those reasons this model does not create conditions propitious to creation and operation of regional parties. A political system of this type creates more attractive conditions for political rivalry of statewide parties and can be a favourable factor attracting the voters to vote on them and not the regional parties. The results obtained by two Silesian parties (the Silesian Regional Party and the Silesians Together) in regional elections of 2018 have confirmed that in the reality of territorial heteronomy statewide parties are more attractive for many party leaders and voters.

Like it was mentioned above, the inspiration for such research were electoral results of the two regional parties in the elections to the Śląskie Voivodeship Assembly in 2018. However, elections in a modern European democratic state cannot be considered only at the level at which they are held. Usually the result of one election has a significant impact on another one (local, regional, state and European). It also characteristic for the Polish case. The territorial heteronomy system has a huge impact on electoral processes, the shape of the party system (including the position of regional parties) and political preferences of voters.

First of all, this rule can be observed in reference to regional elections in Poland. The lack of constitutional subjectivity and clearly defined competences of regional authorities means that in Polish reality they are considered only as an element of the state power. In the speech omade in Otwock Wielki by the leader of the Law and Justice (Prawo i Sprawiedliwość - PiS) party during the electoral campaign on October 15, 2019, Jarosław Kaczyński said: "In Poland - I recall local government authority is also a state power. There are such states and there are theories that say that the self-government is not a state, but a social organization. I, myself, was a student of a professor who was deeply convinced about it, but in Poland a different solution was adopted and the self-government is a state power." (dk/PAP 2018). This assumption underlines the importance of statewide parties, also at the regional level. Such vision of the political representation combined with the lack of legal recognition of regions in the Constitution and the lack of tradition of territorial autonomy in most of the contemporary voivodships of Poland results in the lack of need to create regional parties. It is not a coincidence that they exist only in the Śląskie Voivodeship that has its historical tradition of autonomy. However, even this tradition is not stronger than current interests and political influences of statewide parties, operating in the system of territorial heteronomy. A good illustration of this phenomenon are electoral results of 2018. Law and Justice finally won elections to the Śląskie Voivodeship assembly, offering 
previously to all state citizens - as the governing party - generous social privileges. The effect of having power in the political centre, combined with conservative values, important for many Silesians, ended up to be electorally more important than proposals presented by two regional parties.

Additionally, the adoption of the territorial heteronomy model has its consequences in the state electoral system. The principle that in the elections to Sejm (the first chamber of the Polish parliament) only parties that exceed $5 \%$ of the electoral threshold on whole state territory can participate in the distribution of seats, practically eliminates regional parties from the political rivalry. In this situation, the creation of regional parties does not make much sense for politicians aspiring to obtain a mandate in the central parliament. For a regional party obtaining 5\% of validly of the votes in the whole state territory - even in densely populated Silesia - is the aim impossible to achieve. In the case of Silesia, it is worth to pay attention to the attempt to enter a political cooperation with German minority, which is not obligated - like all other national minorities, recognised legally by the Polish state - to cross a 5\% electoral threshold (Muś 2017). However, so far, such attempts did not bring the politically expected results.

The 2018 political defeat of regional parties in regional elections in Silesia has also political consequences for elections to the European Parliament, held in Poland on May 26, 2019. Also in this case, Polish electoral law requires political parties to exceed $5 \%$ of the electoral threshold in order to participate in the distribution of seats. This is a very restrictive regulation that is impossible to be fulfilled by regional parties. In this situation their independent participation in elections to the European Parliament does not make much sense. However, an analysis of election results to the European Parliament in Poland in 2019 unveils an interesting phenomenon. The defeat of Silesian regionalists in 2018 regional elections was probably one of the reasons why voters in this part of the state territory have voted mainly on the leaders of the most influent statewide parties: the ruling Law and Justice and the opposition called the European Coalition. For all 1.611.781 votes validly casted in the Silesia constituency no. 11, Jadwiga Wiśniewska (the leader of Law and Justice list) got 409.373 votes and Jerzy Buzek (the leader of European Coalition list) - 422.445 votes. This means that the sense of "wasted" vote (casted to parties that did not obtain representation, including regionalists) in regional elections prompted many voters to vote for the leader of supported statewide party to be sure that this time the vote will be "well invested". 
The main purpose of the article was to define the concept of territorial heteronomy. Considerations presented in the text also indicate the most important areas of the behaviour of politicians and voters in conditions of existence of such a model. Furthermore, the author believes that this theoretical approach may be a good basis for conducting further empirical research in this area.

\section{References:}

Ciągwa, J. (1988). Autonomia Śląska: (1922-1939). Katowice: Muzeum Śląskie.

Dandoy, R., Sandri, G. \& De Winter, L. (2018). Patterns of Regional Democracy: Government Forms and Performance in Federal and Decentralised West-European Countries. In: L. Tomini \& G. Sandri (eds.), Challenges of Democracy in the 21st Century: Concepts, Methods, Causality and the Quality of Democracy (pp. 125-141). London-New York: Routledge.

dk/PAP (2018). "To za mało! Za mało! Za mało!". Kaczyński cytuje Broniewskiego. https://www.polsatnews.pl/ wiadomosc/2018-10-15/to-za-malo-za-malo-za-malo-kaczynski-cytuje-broniewskiego/ (16/10/2018)

Dudek, A. (2013). Historia polityczna Polski 1989-2012. Kraków: Wydawnictwo Znak.

Dz. U. 1960, No. 30, item. 168. Act of 14 June 1960 Code of Administrative Procedure Poland.

Dz. U. 1990, No. 16, item. 95. Act of 8 March 1990 on Self-government.

Dz. U. 1997, No. 78, item. 483. Constitution of the Republic of Poland of April 2, 1997, adopted by the National Assembly on April 2, 1997, adopted by the Nation in a constitutional referendum on May 25, 1997, signed by the President of the Republic of Poland on July 16, 1997.

Dz. U. 1998, No. 91, item. 576. Act of 5 June 1998 on Regional (Voivodship) Self-government.

Dz. U. 1998, No. 91, item. 578. Act of 5 June 1998 on Poviat Self-government.

Dz. U. 2017, item. 1453. Act of 13 November 2003 on the incomes of local and regional government units.

Dz. U. 2018, item. 1561. Regulation of the President of the Council of Ministers of August 13, 2018 on the Ordinance of Elections to Municipal Councils, Poviat Councils, Voivodeship Assemblies and District Councils of the Capital City of Warsaw and Elections of Mayors and City Presidents.

Muś, A. (2017). „Zjednoczeni dla Śląska” - Upper-Silesians Support for Regional Initiative. Political Preferences, $14,157-74$.

NIK (2017). Analiza wykonania budżetu państwa i założeń polityki pieniężnej w 2016 roku. Warszawa: Najwyższa Izba Kontroli. https://www.nik.gov.pl/plik/id,14230.pdf (06/10/2017).

Pawlik, P. (2017a). Na Śląsku powstanie nowa partia polityczna. https://slask.onet.pl/na-slasku-powstanie-nowapartia-polityczna/8ynetf3 (30/05/2019).

Pawlik, P. (2017b). Prezes Związu Górnośląskiego: autonomia jest symbolem połaczenia z Polska. https://slask.onet.pl/grzegorz-franki-wspolzalozyciel-slaskiej-partii-regionalnej-wywiad/hmp944g (30.05.2019).

Zasada, M. (2017). Czy Śląska Partia Regionalna powstanie bez jednego ze swoich liderów? https://dziennikzachodni.pl/czy-slaska-partia-regionalna-powstanie-bez-jednego-ze-swoich-liderow/ar/12718174 $(30 / 05 / 2019)$. 